\title{
The Effect of Transformational Leadership on Employee Motivation, Compensation and Employee Performance of the Kupang District Water Supply Company
}

\author{
Frengky Dupe Mintje Ratoe Oedjoe Lenny M. Tamunu; Nursalam \\ Administrative Sciences Doctoral Program, Nusa Cendana University Postgraduate Program \\ Adisucipto Street, Penfui Kupang City, East Nusa Tenggara Indonesia
}

\begin{abstract}
This research is motivated by contradictions of thought contained in organizational theory and empirical findings of previous research on the effects of transformational leadership on employee motivation, compensation, employee performance. Analysis techniques, using Generalized Structured Component Analysis (GSCA). Data sample of 150 respondents as employees in the Kupang District Water Supply Company.This research is motivated by contradictions of thought contained in organizational theory and empirical findings of previous research on the effects of transformational leadership on employee diversity, employee motivation, compensation, employee performance. Analysis techniques, using Generalized Structured Component Analysis (GSCA). Data sample of 150 respondents as employees in the Kupang District Water Supply Company.This study found that transformational leadership has a positive and significant effect on employee diversity, employee motivation, compensation and employee performance. Employee motivation has a positive and significant effect on compensation and employee performance. Compensation has a positive and significant effect on employee performance. This study concludes that the variables of transformational leadership employee motivation, compensation and reasonable compensation have an important role in improving superior performance for the achievement of organizational goals as shared goals. Therefore, attention needs to be paid by policy makers to consider these variables.
\end{abstract}

Keywords: Transformational Leadership, Employee Motivation, Compensation, Employee Performance DOI: $10.7176 / \mathrm{EJBM} / 12-5-08$

Publication date: February $29^{\text {th }} 2020$

\section{INTRODUCTION}

The rapid development of technology brings changes more quickly in the business world. Technological advances make business competition more stringent and difficult to predict, even the function of labor in certain fields of work can be shifted due to the use of robot technology. Advances in technology have positive and negative impacts on the lives of people and companies. Companies can experience progress with technological advances and can also experience setbacks. Both of these phenomena will largely depend on the transfer of technology and knowledge transfer between leaders and citizens of the organization. Technology transfer and knowledge transfer between leaders and members of the organization will have an impact on the performance of the employees of the organization or company.

The phenomenon of the problem faced by the Kupang District Water Supply Company is that the company is unable to serve the water needs of its customers, but the monthly water bill continues, so the customers always fulfill the obligation to pay. Based on this phenomenon, it should be questioned how the performance of the employees of the Kupang District Water Supply Company?

Employee performance has always been the center of attention of leaders and members of the organization in all activities carried out. Employee performance is the result of work or employee achievements that illustrate the success of employees, both personal and group work in doing their work. Performance is work performance calculated based on a comparison between work results achieved and work standards set (Dessler, 2015). Performance focuses on the results of his work. Employee performance can be measured by quality, quantity, production time, work effectiveness, independence, work commitment. Robbins (2015) states performance is "the work of an individual or group of people in an organization for a certain period of time".

An organization or company needs leadership that has integrity and is transformational to influence subordinates to achieve organizational goals. Leaders who always act by applying inspirational motivation, idealism, individual consideration, charisma, and intellectual stimulation to the people they lead in implementing leader's policies, with full awareness of heart to achieve organizational goals as shared goals. Burns (1978) conceptually defines "Transforming Leadership" is a process in which "leaders and followers help each other to advance to a higher level of morals and motivation". Burns established two concepts: "transforming leadership" and "transactional leadership". According to Burns, the transformation approach creates significant changes in the lives of people and organizations.

Bass (1985), extending Burns (1978) by explaining the psychological mechanisms that underlie 
transformational and transactional leadership; Bass also uses the term "transformational" instead of "transforming." Bass added to the initial concept of Burns (1978) to help explain how "transformational leadership can be measured, as well as how it impacts on followers' motivation and performance".

The extent to which a leader has a transformational nature is measured first in terms of its effect on followers. Leaders feel trust, admiration, loyalty and respect for the leader and because the quality of the leader is willing to work harder than originally thought. This result occurs because transformational leaders offer leader followers who are more than just working for their own interests; they provide followers with a vision and mission that inspires and gives them an identity. Leaders change and motivate followers through their ideal influence (previously referred to as charisma), intellectual stimulation and individual consideration. In addition, this leader encourages followers to come up with new and unique ways to challenge the status quo and change the environment to support success. Finally, Burns is different from Bass, because Bass suggests that leadership can simultaneously display transformational and transactional leadership (Bass, 1985).

Saputro and Siagian (2017) explain that leadership is the ability of individuals to influence, motivate, and make others able to contribute effectively to organizational success. The behavior of a leader in an organization is seen as an important indicator that needs attention. The behavior of a leader can be well received by employees if the leader is seen as a source of current satisfaction or future satisfaction (Robbins, 2007). Leadership behavior is motivational if it is able to create employee job satisfaction, through effective support, providing training, guidance and rewards needed to improve employee performance. Studies by Ratnasi (2017); Saputro and Siagian (2017) found transformational leadership to have a positive and significant effect on employee motivation.

Transformational leadership can have a positive influence on performance (Bass et al., 2003). Transformational leadership is: (a) The influence of idealism is a model leader who is a leader behavior that can provide a role model for his employees; (b) Leader's behavior, that is, the leader behaves in a way that motivates the parties around him by giving meaning and challenges to the employee's employees; (c) Intellectual stimulation ie leaders stimulate staff to give praise to employees, develop new ideas; (d) Individual considerations, ie leaders pay attention to individual needs through things focusing on the ability where the leader becomes a coach, communicating directly (Woodet al., 1998). Studies by Ratnasi (2017); Wardani, (2017); Andinasari et al. (2017); Suyanto et al. (2017); Bawaradi et al. (2017); Saputro and Siagian (2017); Hanantoko and Nugraheni (2017); Haryanto (2017) found transformational leadership to have a positive and significant effect on employee performance.

Expectation Theory explains that if someone wants and expects to get something big enough, then the person concerned will be highly motivated to get what he wants. Conversely, if you get something you want is low, then motivation to work will be low (Siagian, 2013). Motives are reasons that encourage someone to do something. Motivation is related to the strength and direction of behavior and the factors that influence people to behave in a certain way to obtain rewards or compensation in financial and non-financial terms (Armstrong, 2009).

Sunyoto (2012) states that motivation is important because motivation is expected that each employee will work hard and enthusiastically to achieve high performance. Mathis and Jakson (2006) suggest factors that affect employee performance, employee capabilities, support received, work performed and employee relations with the organization. Motivation is a driving force that makes someone more eager to work and effective with the aim to get satisfaction through high performance achievements. Studies by Ratnasi (2017); Andinasari et al. (2017); Yunus and Suwandi (2017); Hanantoko and Nugraheni (2017); Haryanto (2017) found positive and significant effect employee motivation towards employee performance.

Robbins (1993) describes compensation that can improve work performance and job satisfaction, if the award is received: (1) appropriate to the abilities and productivity of employees; (2) about work performance; and (3) adjusting individual needs. In this case the company must pay attention to approving the provision of fair compensation for employees. Employees value inadequate compensation, they will experience a decrease in employee performance and job satisfaction, while opposing high compensation, it will increase employee performance and job satisfaction. Studies by Qustolani (2017) found positive and significant support for employee performance.

Human resource management that is well managed will provide benefits to increase competitive advantage. Company management needs to pay attention to leadership, employee motivation, compensation and employee performance has functioned optimally to achieve organizational goals. Transformational leadership is expected to manage varied employee motivations, provide reasonable compensation in an effort to improve employee performance and achieve organizational goals as shared goals.

This research is based on theoretical studies and previous research studies and developed a research model involving 4 variables: Transformational leadership, employee motivation, compensation and employee performance. This study uses an analysis tool "Generalized Structured Component Analysis (GSCA)" based on Structural Equation Modeling (SEM) that is able to analyze data from variables studied in a structured manner and with a large number of indicators. This research focuses on the problems which are formulated, as follows: 


\subsection{Research Question}

1) Does transformational leadership have a positive and significant effect on employee motivation?

2) Does transformational leadership have a positive and significant effect on employee performance?

3) Does employee motivation have a positive and significant effect on compensation?

4) Does employee motivation have a positive and significant effect on employee performance?

5) Does compensation have a positive and significant effect on employee performance?

\subsection{Research Objectives}

1) Test and explain the effect of transformational leadership on employee motivation.

2) Test and explain the effect of transformational leadership on employee performance.

3) Test and explain the effect of employee motivation on compensation.

4) Test and explain the effect of motivation on employee performance.

5) Test and explain the effect of compensation on employee performance.

\section{LITERATURE REVIEW}

\subsection{The Effect of Transformational Leadership on Employee Motivation}

Transformational leadership is an approach used by leaders to influence subordinates to achieve organizational goals (Bass, 1985). Transformational leadership is a leader who motivates his subordinates and changes individuals to improve their quality so that they are more enthusiastic at work and give encouragement not to precede personal interests (Locander et al., 2002). Motivation is defined as a set of forces that make people behave in certain ways (Moorhead and Griffin, 2013). Motivation is a set of strengths that causes people to engage in behavior. Motivation is a process of high level of willingness to do business in order to achieve organizational goals conditioned by the ability of businesses to meet individual needs (Robbins and Coulter, 2007). Motivation as a concept that describes the power that exists in each individual who initiates, encourages and directs certain behaviors (Gibson et al., 2006). Motivation is the energy that moves people to achieve the expected goals (Armstong, 2009). Motivation comes from two dimensions: (1) Extrinsic or artificial motivation (something done to motivate people) and (2) intrinsic motivation (encouragement from within a person).

Saputro and Siagian (2017) explain that leadership is the ability of individuals to influence, motivate, and make others able to contribute effectively to organizational success. The behavior of a leader in an organization is seen as an important indicator that needs attention. The behavior of a leader can be well received by employees if the leader is seen as a source of current satisfaction or future satisfaction (Robbins, 2007). Leadership behavior is motivational if it is able to create employee job satisfaction, through effective support, providing training, guidance and rewards needed to improve employee performance. Studies by Ratnasi (2017); Saputro and Siagian (2017) found transformational leadership to have a positive and significant effect on employee motivation. Transformational leadership that is getting better can motivate employees through the best approach used by leaders to influence subordinates to achieve organizational goals, by ways of acting that apply inspirational motivation, idealism, individual consideration, charisma, and intellectual stimulation to the people they lead in implement leaders' policies, with full awareness of heart to achieve organizational goals as shared goals.

\subsection{The Effect of Transformational Leadership on Employee Performance}

Transformational leadership can have a positive influence on performance (Bass and Avolin, 2003). Transformational leadership is: (a) The influence of idealism is a model leader who is a leader behavior that can provide a role model for his employees; (b) Leader's behavior, that is, the leader behaves in a way that motivates the parties around him by giving meaning and challenges to the employee's employees; (c) Intellectual stimulation ie leaders stimulate staff to give praise to employees, develop new ideas; (d) Individual considerations, ie leaders pay attention to individual needs through focusing on the ability where the leader becomes a coach, communicating directly (Wood et al., 1998). Studies by Ratnasi (2017); Wardani, (2017); Andinasari et al. (2017); Suyanto et al. (2017); Bawaradi et al. (2017); Saputro and Siagian (2017); Hanantoko and Nugraheni (2017); Haryanto (2017) found transformational leadership to have a positive and significant effect on employee performance. Transformational leadership is expected to improve employee performance through the best approach used by leaders to influence subordinates to achieve organizational goals, by ways of acting that apply inspirational motivation, idealism, individual consideration, charisma, and intellectual stimulation to the people they lead in carrying out leader policies, with full awareness of the heart to achieve organizational goals as a common goal.

\subsection{The Effect of Employee Motivation Against Compensation}

Expectation Theory explains that if someone wants and expects to get something big enough, then the person concerned will be highly motivated to get what he wants. Conversely, if you get something you want is low, then motivation to work will be low (Siagian, 2013). Motives are reasons that encourage someone to do something. Motivation is related to the strength and direction of behavior as well as the factors that influence people to behave 
in a certain way to obtain rewards or compensation, both financial and non-financial.

Motivation is generally divided into two, namely positive motivation and negative motivation (Armstrong, 2009). Positive motivation is something that encourages others to behave in accordance with the wishes of the motivator by giving money, appreciation and others, while negative motivation is something that encourages others to behave according to the motivator's desires through fear for example by punishment or sanctions. Motivation is the energy that moves people to achieve the expected goals (Armstong, 2009). Motivation comes from two dimensions: (1) Extrinsic or artificial motivation (something done to motivate people) and (2) intrinsic motivation (encouragement from within a person).

Motivation and Money. Money in the form of salary or other remuneration is the clearest extrinsic gift. Money seems to provide the happiness most people want. Doubts are thrown on the effectiveness of money by Herzberg et al. (1957) because money cannot produce true satisfaction. There is something in this, especially for people with fixed salaries or salary levels who do not benefit directly from incentive schemes. People might feel good when they get a raise; Apart from the extra money this is a very tangible form of recognition and an effective way to help people feel valued. But this feeling of euphoria can quickly disappear. Other dissatisfaction from Herzberg's list of cleanliness factors, such as working conditions or management quality, can be greater in the minds of some people when they fail to get the satisfaction needed from the job itself. It is realized that different people have different needs and desires. Some people will be far more motivated by money than others.

Instrumental theory states that people only work for money. The theory emerged in the second half of the 19 th century with an emphasis on the need to rationalize employment and economic outcomes. Instrumentality theory assumes that people will be motivated to work if there are rewards or penalties directly related to their performance; so rewards depend on effective performance. The theory of oralisation is rooted in scientific management methods (Taylor, 1911) who wrote: "It is not possible in the long run to make workers to work harder than ordinary people around him, unless they are sure of their salary and salary increases that are permanent." This theory of oralisation provides a reason to pay incentives, even though it is a dubious decision. The principle of reinforcement is used to motivate someone exclusively to an external control system and can succeed in some circumstances, but that and fail to recognize a number of other human needs. It also fails to appreciate the fact that the formal control system can be seriously affected by informal relations between workers (Armstrong, 2009). Employee behavior at work is strongly influenced by compensation given by the organization, because after all workers always try to meet their daily needs, which are expected can be fulfilled by the organization through salaries, benefits, incentives, bonuses. Compensation provided by the organization to employees is a remuneration for employees who have provided work results to the organization or company.

"Expectancy Theory" formulated by Vroom (1964). Vroom explains valence means value, instrumentality is the belief that if people do one thing, it will lead to another, and hope is the probability that an action or effort will produce an outcome. An outcome expected by employees to get from the company is compensation, someone is innovated to do work because he expects compensation. The better the motivation of employees will result in an increase in compensation which includes salaries, benefits, incentives, services obtained by employees, or in other words the existence of compensation depends on the motivation of employees who cover extrinsic motivation and intrinsic motivation. Employees who want to get high compensation must also have high motivation to work and contribute to the company's income. Employee motivation must be well managed by management in order to achieve organizational goals.

\subsection{The Effect of Employee Motivation on Employee Performance}

Sunyoto (2012) states that motivation is important because with motivation it is expected that every employee will work hard and enthusiastically to achieve high performance. Mathis and Jakson (2006) suggested that the factors affecting employee performance were employee motivation, employee ability, support received, the state of work performed and the employee's relationship with the organization. Motivation is a driving force that makes someone more eager to work effectively and integrated with the aim of getting satisfaction through high performance achievements. Studies by Ratnasi (2017); Andinasari et al. (2017); Yunus and Suwandi (2017); Hanantoko and Nugraheni (2017); Haryanto (2017) found employee motivation to have a positive and significant effect on employee performance. What cannot be assumed is that money motivates everyone in the same way and to the same degree. It is naive to think that the introduction of performance-related payment schemes will magically transform everyone into a highly motivated and high-achieving individual (Armstrong, 2009).

"Expectancy Theory" formulated by Vroom (1964). Vroom explains valence means value, instrumentality is the belief that if people do one thing, it will lead to another, and hope is the probability that an action or effort will produce an outcome. An outcome expected by employees to get from the company is compensation, someone is innovated to do work because he expects compensation, in the end employees will be very eager to work and improve performance. The better motivation of employees will result in an increase in employee performance which includes quality, production time, independence, work effectiveness, work commitment, and quantity obtained by employees, or in other words the existence of employee performance depends on employee motivation 
which includes extrinsic motivation and intrinsic motivation. Employees who want to obtain high performance must also have high motivation to work and contribute to the company's income. Employee motivation must be well managed by management in order to achieve organizational goals.

\subsection{The Effect of Compensation on Employee Performance}

Robbins (1993) explains that compensation can play a role in increasing work performance and job satisfaction, if compensation is felt (a) to be appropriate with the ability and productivity of employees; (b) relating to work performance; and (c) adjusting individual needs. In this case the company must pay good attention to the arrangements for giving compensation to employees properly. The employees assess the compensation provided is inadequate, then the performance and job satisfaction of employees will decrease, conversely if the compensation given is high then the employee's performance and job satisfaction will increase. Studies by Qustolani (2017) found compensation has a positive and significant effect on employee performance.

It is alleged that compensation improvements will result in changes in employee performance which include quality, production time, independence, work effectiveness, work commitment, and quantity obtained by employees, or in other words the existence of employee performance depends on compensation which includes extrinsic motivation and intrinsic motivation. Employees who want to obtain high performance must be given high benefits, incentives, salaries, and rewards as a reward for contributing to the company's income. Compensation must be managed well by management in order to motivate employees to work harder to achieve organizational goals.

Achieving high levels of employee performance is highly dependent on the success of leadership and the people or members of the organization synergistically contribute positively to the planning process and implementation of tasks and responsibilities as organizational citizens to achieve organizational goals. Transformational leadership is expected to be the best approach used by leaders to influence subordinates, in order to achieve organizational goals, by ways of acting that apply inspirational motivation, idealism, individual consideration, charisma, and intellectual stimulation to the people they lead in implementing policies leader policy, with full awareness of the heart to achieve organizational goals as shared goals. Transformational leadership is expected to be able to manage motivate employees and provide reasonable compensation to employees and contribute to improving employee performance. Based on theoretical studies as described and several previous research models, the research model was developed as in Figure 1, as follows:

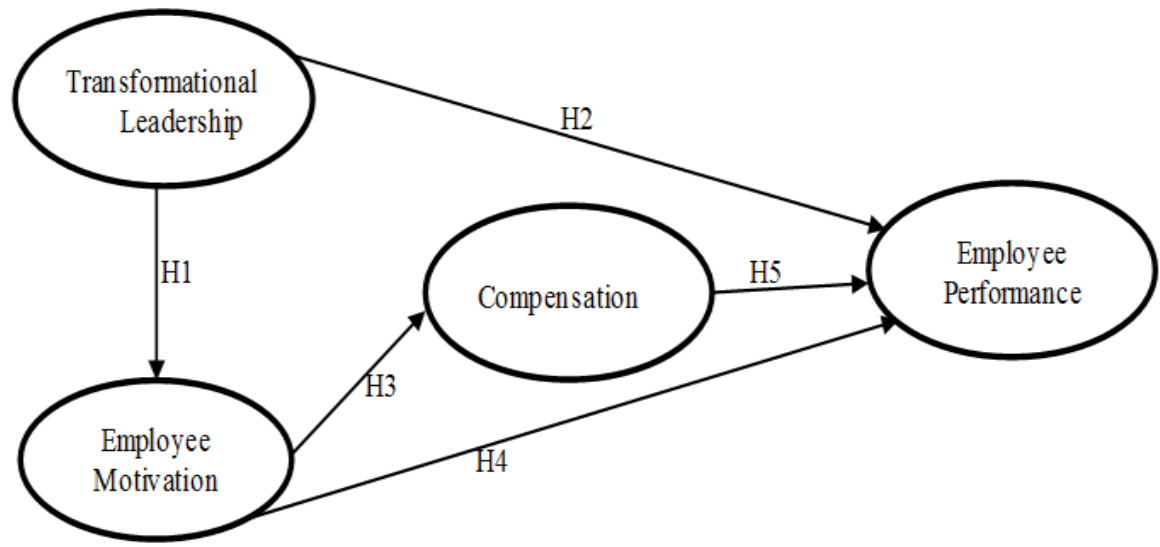

Figure 1. Research Conceptual Framework

Source: Developed for this Study (Dupe, 2019)

\subsection{Research Hypothesis}

H1: Transformational leadership has a positive and significant effect on employee motivation.

H2: Transformational leadership has a positive and significant effect on employee performance.

H3: Employee motivation has a positive and significant effect on compensation.

H4: Employee motivation has a positive and significant effect on employee performance.

H5: Compensation has a positive and significant effect on employee performance.

\section{RESEARCH METHODS}

This type of research is a type of explanatory research, conducted with the intention of providing an explanation of the causal relationship or influence between variables through testing hypotheses. Explanatory research is to examine the influence between hypothesized variables. This study uses primary data and research objectives should be achieved through quantitative methods. The quantitative approach aims to test the theory by testing and 
explaining the effect of exogenous variables on endogenous variables, which are measured through instruments, and analysis using statistical procedures and hypothesis testing (Creswell, 2009).

This research was conducted on employees of the Kupang District Water Supply Company, East Nusa Tenggara Province, Indonesia. The time of data collection is conducted from July to November 2019. The method of determining the sample is random sampling. The sample is part of the population observed, because the population observed is relatively small, only 220 people, so the sample in this study was taken 150 people or ( $88.5 \%$ of 220 ). The reason for taking a sample was 150 people or $68,18 \%$ because of all 220 questionnaires, 150 respondents were received and completely filled out with only 150 questionnaires.

Data collection through survey questionnaires for primary data based on respondents' perceptions of Transformasional Leadership Variables (X), Employee Motivation Variables ( $\left.\mathrm{Y}_{1}\right)$, Compensation Variables $\left(\mathrm{Y}_{2}\right)$, and Employee Performance Variables $\left(\mathrm{Y}_{3}\right)$. Measurement of perceptions of respondents using a Likert Scale. According to Simamora (2004) Likert Scale is used to measure attitudes, opinions of people or groups of people about social events or symptoms. Likert scale that can be used to measure a person's perceptions, for example measurement: approval, trust, support, priority, probability of frequency, level, and others.

The Likert Scale in this study uses scores of 1 to 5, which represent perceptions of levels. The results of data measurement are in the interval category. This is reinforced by Sekaran (2003) states that the Likert Scale can produce interval data, also by Sharma (1996) states that a measurement will produce an interval scale if the distance of the category is a draw or the same. More details on the measurement scale can be specified as in table 1, below: Table 1. Measurement of Likert Scale

\begin{tabular}{|l|l|l|}
\hline Score & Meaning & Explanation \\
\hline 1 & Very Low & If the meaning of the statement is perceived to be very low / very inappropriate. \\
\hline 2 & Low & If the meaning of the statement is perceived to be low / inappropriate. \\
\hline 3 & Middle & If the meaning of the statement is perceived to be quite high / quite appropriate. \\
\hline 4 & High & If the meaning of the statement is perceived as high / appropriate \\
\hline 5 & Very High & If the meaning of the statement is perceived to be very high it is very appropriate. \\
\hline
\end{tabular}

Source: Simamora (2004), adapted to the context of the study.

\subsection{Instrument Validity Test}

Before conducting data collection, it is necessary to test the validity and reliability of research instruments to ensure that the instruments used are valid and reliable. The validity test of the research instrument was carried out on 30 respondents of the research location. The validity test of the instrument is useful to find out whether the questions on the questionnaire can produce correct information / data, so that improvements can be made to the research instruments, or items that are not worthy of being replaced / discarded.

Testing is done by correlating the score of each item with the total score of each indicator variable, using Pearson Correlation. If the correlation coefficient ( $\mathrm{r}$ count $\geq 0.30$ ) then the item question is declared valid. The results of the instrument validity test on 30 respondents using the SPSS for Windows version 22 tool, to find out the instruments used in the study were valid. The research instrument is considered valid, if the value of the correlation coefficient of the question item with the total score is greater the table correlation value (rabel). Correlation test results obtained correlation coefficient values of all question items used in this study greater than 0.30 (cut off). 
Table 2. Summary of Testing Results for Instrument Validity

\begin{tabular}{|c|c|c|c|c|c|}
\hline Variables & Indicators & Item Symbol & Correlation coefficient & Cut Off & Information \\
\hline \multirow{5}{*}{$\begin{array}{l}\text { Transformational } \\
\text { Leadership } \\
\text { (X) }\end{array}$} & Idealism & $\mathrm{X} 1.1$ & 0,874 & 0.30 & Valid \\
\hline & Intellectual stimulation & $\mathrm{X} 1.2$ & 0,696 & 0.30 & Valid \\
\hline & Inspirational Motivation & $\mathrm{X} 1.3$ & 0,549 & 0,30 & Valid \\
\hline & $\begin{array}{l}\text { Individual } \\
\text { Considerations }\end{array}$ & $\mathrm{X} 1.4$ & 0,836 & 0.30 & Valid \\
\hline & Charisma & $\mathrm{X} 1.5$ & 0,823 & 0.30 & Valid \\
\hline \multirow{8}{*}{ Employee Motivation $\left(\mathrm{Y}_{1}\right)$} & \multirow{6}{*}{$\begin{array}{l}\text { Extrinsic Motivation } \\
(\mathrm{EM})\end{array}$} & Y2.1 & 0,719 & 0.30 & Valid \\
\hline & & Y2.2 & 0,706 & 0.30 & Valid \\
\hline & & Y2.3 & 0,676 & 0.30 & Valid \\
\hline & & Y2.4 & 0,710 & 0.30 & Valid \\
\hline & & Y2.5 & 0,676 & 0.30 & Valid \\
\hline & & Y2.6 & 0,783 & 0.30 & Valid \\
\hline & \multirow{2}{*}{$\begin{array}{l}\text { Intrinsic Motivation } \\
\text { (IM) }\end{array}$} & Y2.7 & 0,784 & 0.30 & Valid \\
\hline & & Y2.8 & 0,772 & 0.30 & Valid \\
\hline \multirow{4}{*}{ Compensation $\left(\mathrm{Y}_{2}\right)$} & Salary & Y3.1 & 0,635 & 0.30 & Valid \\
\hline & Reward & Y3.2 & 0,827 & 0.30 & Valid \\
\hline & Incentive & Y3.3 & 0,688 & 0.30 & Valid \\
\hline & Benefits & Y3.4 & 0,670 & 0.30 & Valid \\
\hline \multirow{6}{*}{$\begin{array}{l}\text { Employee Performance } \\
\left(\mathrm{Y}_{3}\right)\end{array}$} & Quality & Y1.1 & 0,852 & 0.30 & Valid \\
\hline & Quantity & Y1.2 & 0,645 & 0.30 & Valid \\
\hline & Production time & Y1.3 & 0,892 & 0.30 & Valid \\
\hline & Work Effectiveness & Y1.4 & 0,927 & 0.30 & Valid \\
\hline & Independence & Y1.5 & 0,813 & 0.30 & Valid \\
\hline & Work Commitment & Y1.6 & 0,841 & 0.30 & Valid \\
\hline
\end{tabular}

Source: The results of the research instrument test were processed in 2019.

\subsection{Instrument Reliability Test}

Instrument reliability is an index that shows the extent to which a measuring instrument can be trusted or relied upon. The instrument is reliable when used several times to measure the same object and produce the same data (Sugiyono, 2012). The method used is the Cronbach Alpha correlation coefficient. The research instrument was stated to be reliable if it had Cronbach Alpha $\geq 0.60$. The instrument reliability test results on 30 respondents using the same program are known, that the research instrument used is reliable, because all reliability coefficient values (Cronbach's Alpha) on the variables used in this study are greater than 0.6 (cut off). All statement items in Employee Transformational Leadership Variables, Employee Motivation Variables, Compensation Variables, and Employee Performance Variables, are stated to be reliable or consistent in measuring these variables, so that they can be used as a data collection tool in this study.

Table 3. Summary of Instrument Reliability Test Results

\begin{tabular}{|l|c|c|c|c|}
\hline Variables & Amount of Item & Cronbach's Alpha & Cut Off & Information \\
\hline Transformational Leadership $(\mathrm{X})$ & 5 & 0,811 & 0.6 & Reliable \\
\hline Employee Motivation $\left(\mathrm{Y}_{1}\right)$ & 8 & 0,874 & 0.6 & Reliable \\
\hline Compensation $\left(\mathrm{Y}_{2}\right)$ & 4 & 0,834 & 0.6 & Reliable \\
\hline Employee Performance $\left(\mathrm{Y}_{3}\right)$ & 6 & 0,884 & 0.6 & Reliable \\
\hline
\end{tabular}

Source: The results of the research instrument test were processed in 2019

\subsection{Data Analysis Methods}

\subsubsection{Inferential Statistical Analysis with GSCA Method}

Inferential statistical analysis is used in accordance with the formulation of the problem, research objectives, and the hypothesis of this study is Generalized structured component analysis (GSCA). This analysis approach uses the least square method in the parameter estimation process. GSCA was developed to avoid the shortcomings of PLS (partial least square), which is equipped with global optimization procedures and also maintains local optimization procedures (such as PLS). The GSCA method can also be applied to influences between complex variables (can be recursive and not recursive), involving higher-order components (factors) and multi-group comparisons. GSCA is a new method of component-based SEM, which can be applied to very small samples. GSCA can be used in structural models involving variables with reflective and or formative indicators.

The steps of Data Analysis with GSCA are as follows: 
1) Open the GeSCA website and upload data.

2) Designing a structural model (influence between latent variables). Structural models that show the influence between latent variables based on the formulation of the problem or research hypothesis.

3) Designing a measurement model is determining the nature of the indicators of each latent variable, whether reflexive or formative.

4) Runing (calculation)

5) Construction of path diagrams in the research model.

6) Conversion of path diagrams into system equations, including:

(1) Explaining the influence of latent variables and indicators, also called the measurement model, defines the characteristics of latent variables with indicators.

(2) Explain the influence between latent variables (structural models), which describes the influence between latent variables based on the substantive theory of research. Without losing its general properties, it is assumed that latent variables and indicators or manifest variables are standardized, so that constants can be removed from the model (constant $=0$ ).

(3) Parameter estimation. The parameter estimation method (estimation) is the least square method. The structural model and measurement model are integrated into one model, so the parameter estimation process is oriented towards minimizing the integrated residual model. Estimating parameters based on original sample data, including: Weight and Loading estimate is to get latent variable data, generally parameter estimation using eigen value and eigen vector approach. The path coefficient estimate is the coefficient of influence between latent variables, used by ALS. Parameter estimation Based on resampling data (bootstrap sample), including: Means from Weight, Loading and Path coefficient, that is, the estimated parameter is a mean from the subsample, using the bootstrap resampling method.

\section{Research Result}

4. 1 Staticfic description of respondents' answers for 23 items from 4 research variables, as in table 4 , is as follows:

Tabel 4. Descriptive Statistics

\begin{tabular}{|c|c|c|c|c|c|}
\hline Items, Variable Indicators & $\mathrm{N}$ & Minimum & Maximum & Mean & Std. Deviation \\
\hline $\mathrm{X} 1.1$ & 150 & 2,0 & 5,0 & 3,70 & 0,97 \\
\hline $\mathrm{X} 1.2$ & 150 & 2,0 & 5,0 & 3,61 & 0,85 \\
\hline $\mathrm{X} 1.3$ & 150 & 2,0 & 5,0 & 3,70 & 0,82 \\
\hline $\mathrm{X} 1.4$ & 150 & 2,0 & 5,0 & 3,73 & 0,81 \\
\hline $\mathrm{X} 1.5$ & 150 & 2,0 & 5,0 & 3,67 & 0,80 \\
\hline Y1.1 & 150 & 2,0 & 5,0 & 4,09 & 0,86 \\
\hline Y1.2 & 150 & 2,0 & 5,0 & 3,91 & 0,83 \\
\hline Y1.3 & 150 & 2,0 & 5,0 & 3,94 & 0,91 \\
\hline Y1.4 & 150 & 2,0 & 5,0 & 3,91 & 0,93 \\
\hline Y1.5 & 150 & 2,0 & 5,0 & 4,04 & 0,87 \\
\hline Y1.6 & 150 & 2,0 & 5,0 & 3,99 & 0,89 \\
\hline Y1.7 & 150 & 2,0 & 5,0 & 3,83 & 1,03 \\
\hline Y1.8 & 150 & 2,0 & 5,0 & 3,77 & 0,97 \\
\hline Y2.1 & 150 & 2,0 & 5,0 & 3,93 & 0,81 \\
\hline Y2.2 & 150 & 2,0 & 5,0 & 3,98 & 0,81 \\
\hline Y2.3 & 150 & 2,0 & 5,0 & 3,96 & 0,83 \\
\hline Y2.4 & 150 & 2,0 & 5,0 & 3,93 & 0,83 \\
\hline Y3.1 & 150 & 2,0 & 5,0 & 3,92 & 0,76 \\
\hline Y3.2 & 150 & 2,0 & 5,0 & 3,73 & 0,78 \\
\hline Y3.3 & 150 & 1,0 & 5,0 & 3,81 & 0,77 \\
\hline Y3.4 & 150 & 2,0 & 5,0 & 3,76 & 0,76 \\
\hline $\mathrm{Y} 3.5$ & 150 & 2,0 & 5,0 & 3,79 & 0,76 \\
\hline Y3.6 & 150 & 2,0 & 5,0 & 3,75 & 0,81 \\
\hline Valid N (listwise) & 150 & & & & \\
\hline
\end{tabular}

\section{2 Testing Linear Assumptions}

The linearity test results are presented in table 5, as follows: 
Table 5. Linearity Test Results

\begin{tabular}{|l|l|r|r|}
\hline \multicolumn{2}{|l|}{ Relationship between Variables } & \multirow{2}{*}{ F } & \multirow{2}{*}{ Probability } \\
\cline { 1 - 2 } Exogenous & Endogenous & \multicolumn{1}{|c|}{0.000} \\
\hline Transformational Leadership (X) & Employee Motivation (Y1) & 99,324 & 0.000 \\
\hline Transformational Leadership (X) & Employee Performance (Y3) & 258,476 & 0.000 \\
\hline Employee Motivation (Y1) & Compensation (Y2) & 79,198 & 0.000 \\
\hline Employee Motivation (Y1) & Employee Performance (Y3) & 134,997 & 0.000 \\
\hline Compensation (Y2) & Employee Performance (Y3) & 144,075 & \\
\hline Significant At .05 Level
\end{tabular}

Source: Linearity Test Results processed in 2019

Linearity testing is intended to determine the linearity of the relationship between exogenous variables and endogenous variables. Test criteria states that if the probability value must be smaller than 0.05 . If the probability value must be less than 0.05 , then it can be stated that there is a significant linear relationship between the exogenous variable and the endogenous variable.

\subsection{Results of the Measurement Model (Outer Models)}

Outer loading value is the weight value of each indicator as a measure of latent variables. The indicator that has the largest outer loading is considered as the strongest / dominant variable gauge. The outer loading results of the item, the measured latent variable indicator, are obtained through GSCA Bootstrap calculations which also produce a critical ratio (CR) value similar to the statistical $T$ value, if the outer loading value is above 0.5 and the $C R$ value is greater than $1.96 \mathrm{~T}$ table, then it was decided significant.

\subsubsection{Transformational Leadership Variable (X)}

The transformational leadership variable $(\mathrm{X})$ is measured by 5 items of research statements that are used as parameters to measure this variable. Item / Indicator of transformational leadership variables (X) are Idealism (X1.1), Intellectual Stimulation (X1.2), Individual Consideration (X1.3), Inspirational Motivation (X1.4), and charisma (X1.5). All research items / indicators are valid and reliable in measuring transformational leadership variables (X). More clearly the answers or perceptions of 150 respondents towards the transformational leadership variable expressed by employees of the Kupang District Water Supply Company are shown in table 6.

Table 6. Transformational Leadership Variable Measurement Model (X)

\begin{tabular}{|c|c|c|c|c|}
\hline \multirow{2}{*}{ Items, Variable Indicators } & \multicolumn{2}{|c|}{ Convergent Validity } & \multicolumn{2}{c|}{ Composite Reliability } \\
\cline { 2 - 3 } & Loading Factor $>0.5$ & AVE $>0.5$ & Alpha $\geq 0.6$ \\
\cline { 2 - 3 } & Loading & Valid & AVE & Reliable \\
\hline X1.1 & 0.868 & Valid & & \multirow{2}{*}{$\mathbf{0}$} \\
\hline X1.2 & 0.868 & Valid & \multirow{2}{*}{$\mathbf{0 . 7 8 3}$} \\
\hline X1.3 & 0.894 & Valid & \\
\hline X1.4 & 0.880 & Valid & & \\
\hline CR 1.5 & 0.912 & Valid & & \\
\hline
\end{tabular}

Source: Results of the GSCA Analysis were processed in 2019.

\subsubsection{Employee Motivation Variable $\left(\mathrm{Y}_{1}\right)$}

Employee Motivation Variable (Y1) is measured by 8 research items that are used as parameters to measure this variable. These indicators are Extrinsic Motivation, and Intrinsic Motivation. More clearly the answers or perceptions of 150 respondents to the employee motivation variable (Y1) expressed by employees of the Kupang District Water Supply Company. The results of the GSCA analysis show that all question items have a loading factor value greater than 0.5 which means it is valid and has a AVE greater than 0.5, has an alpha greater than 0.6 which means that all indicators are valid and reliable as a measure of employee motivation variables (Y1), in table 7. 
Table 7. Employee Motivation Variable Measurement Model ( $\left.Y_{1}\right)$

\begin{tabular}{|c|c|c|c|c|}
\hline \multirow{3}{*}{$\begin{array}{l}\text { Items, Variable } \\
\text { Indicators }\end{array}$} & \multicolumn{2}{|c|}{ Convergent Validity } & \multicolumn{2}{|c|}{ Composite Reliability } \\
\hline & \multicolumn{2}{|c|}{ Loading Factor $>0.5$} & AVE $>0.5$ & Alpha $\geq 0.6$ \\
\hline & Loading & Valid & AVE & Reliable \\
\hline Y1.1 & 0.940 & Valid & \multirow{8}{*}{0.771} & \multirow{8}{*}{0.956} \\
\hline Y1.2 & 0.881 & Valid & & \\
\hline Y1.3 & 0.927 & Valid & & \\
\hline Y1.4 & 0.864 & Valid & & \\
\hline $\mathrm{Y} 1.5$ & 0.900 & Valid & & \\
\hline Y1.6 & 0.888 & Valid & & \\
\hline $\mathrm{Y} 1.7$ & 0.792 & Valid & & \\
\hline Y1.8 & 0.822 & Valid & & \\
\hline
\end{tabular}

Source: The results of the GSCA analysis were processed in 2019.

4.3.3 Compensation Variable $\left(\mathrm{Y}_{2}\right)$

The compensation variable (Y2) is measured by 4 research items, as in the table 8 . The compensation variable (Y2) is the Salary (Y2.1), Allowances (Y2.2), Incentives (Y2.3), Services Services (Y2.4). All research items / indicators are valid and reliable in measuring compensation variable (Y2). The answers or perceptions of 150 respondents were clearer about the compensation variable (Y2) expressed by the employees of the Kupang District Water Supply Company. The results of the GSCA analysis show that all question items have a loading factor value greater than 0.5 which means it is valid and has a AVE greater than 0.5 , has an alpha greater than 0.6 which means that all indicators are valid and reliable as a measure of compensation variable (Y3), indicated in table 8.

Table 8. Measurement Model of Compensation Variables (Y2)

\begin{tabular}{|c|c|c|c|c|}
\hline \multirow{3}{*}{ Items, Variable Indicators } & \multicolumn{2}{|c|}{ Convergent Validity } & \multicolumn{2}{|c|}{ Composite Reliability } \\
\hline & \multicolumn{2}{|c|}{ Loading Factor $>0.5$} & $\mathrm{AVE}>0.5$ & Alpha $\geq 0.6$ \\
\hline & Loading & Valid & AVE & Reliable \\
\hline Y2.1 & 0.971 & Valid & \multirow{4}{*}{0.933} & \multirow{4}{*}{0.976} \\
\hline Y2.2 & 0.962 & Valid & & \\
\hline Y2.3 & 0.968 & Valid & & \\
\hline Y2.4 & 0.961 & Valid & & \\
\hline
\end{tabular}

Source: The results of the GSCA analysis were processed in 2019.

4.3.4 Employee Performance Variable (Y3)

Employee Performance Variable (Y3) is measured by the research item used as a parameter to measure this variable. Employee Performance Items / Indicators (Y3) are Quality (Y3.1), Quantity (Y3.2), Production Time (Y3.3), Work Effectiveness (Y3.4), Independence (Y3.5), Work Commitment ( Y3.6). All research items / indicators are valid and reliable in measuring Employee Performance variables (Y3). More clearly the answers or perceptions of 150 respondents to the employee performance variable (Y3) expressed by employees of the Kupang District Water Supply Company are shown in table 9.

Table 9. Employee Performance Variable Measurement Model (Y3)

\begin{tabular}{|c|c|c|c|c|}
\hline \multirow{2}{*}{ Items, Variable Indicators } & \multicolumn{2}{|c|}{ Convergent Validity } & \multicolumn{2}{c|}{ Composite Reliability } \\
\cline { 2 - 3 } & \multicolumn{2}{|c|}{ Loading Factor $>0.5$} & AVE $>0.5$ & Alpha $\geq 0.6$ \\
\cline { 2 - 3 } & Loading & Valid & AVE & \\
\hline$Y_{3.1}$ & 0.890 & Valid & \\
\hline$Y_{3.2}$ & 0.931 & Valid & \\
\hline$Y_{3.3}$ & 0.913 & Valid & \multirow{2}{*}{0.968} \\
\hline$Y_{3.4}$ & 0.948 & Valid & \\
\hline$Y_{3.5}$ & 0.954 & Valid & & \\
\hline$Y_{3.6}$ & 0.933 & Valid & & \\
\hline CR* significant at .05 level & \multicolumn{2}{|c}{} \\
\hline
\end{tabular}

Source: The results of the GSCA analysis were processed in 2019.

\subsection{Inner Model Test Results}

Based on the theory and empirical research in chapter 2, and the conceptual model that has been developed, then develops an inner model to explain the correlation between the independent latent variable and the dependent latent variable based on the substance of the theory. The inner model defines how each independent latent variable correlates with the dependent latent variable. The value of the path coefficient of influence between the 
independent latent variables on the dependent latent variable, obtained through GSCA calculations and significant tests obtained through bootstrapping which results in a critical ratio $(\mathrm{CR})$ value equal to the $\mathrm{T}$ value. Hypothesis testing is done with the value of the critical ratio (CR) with the value of the $T$ table on each connecting path that affects the latent variables. Based on the results of the GSCA analysis, a hypothetical tested model is obtained, as in table 10.

Table 10. Structural Model Test Results (Inner Model)

\begin{tabular}{|l|c|c|c|c|l|l|}
\hline \multirow{2}{*}{ Hypothesis } & \multirow{2}{*}{ Path } & \multicolumn{2}{|c|}{ Path Coefficients } & \multicolumn{2}{|c|}{ Information } \\
\cline { 3 - 6 } & & Estimate & SE & CR & \multicolumn{2}{|c|}{} \\
\hline H1 & X->Y1 & 0.648 & 0.059 & $11.01^{*}$ & Significant & H1 accepted \\
\hline H2 & X->Y3 & 0.495 & 0.073 & $6.81^{*}$ & Significant & H2 accepted \\
\hline H3 & Y1->Y2 & 0.595 & 0.072 & $8.28^{*}$ & Significant & H3 accepted \\
\hline H4 & Y1->Y3 & 0.242 & 0.071 & $3.39^{*}$ & Significant & H4 accepted \\
\hline H5 & Y2->Y3 & 0.245 & 0.061 & $3.98^{*}$ & Significant & H5 accepted \\
\hline CR* $=$ Significant at 0.05 level
\end{tabular}

Sumber: Hasil analisis GSCA diolah pada tahun 2019.

\section{DISCUSSION}

\subsection{Discussion of Hypothesis Testing Results}

\subsubsection{The Effect of Transformational Leadership on Employee Motivation}

The effect of transformational leadership on employee motivation, as evidenced by statistically empirical data shows positive and significant path coefficients. The positive path coefficient means that transformational leadership is better managed and will increase employee motivation. The theoretical implication of this research is the improvement of transformational leadership will result in changes in employee motivation, or in other words the existence of employee motivation depends on transformational leadership. Employee motivation includes extrinsic motivation and intrinsic motivation can be managed well by a leader in order to achieve organizational goals. (H1 accepted) which states that "Transformational leadership has a significant effect on employee motivation". This happens, because transformational leadership prioritizes idealism, intellectual stimulation, individualized consideration, inspirational motivation, to influence employees in order to achieve organizational goals as shared goals.

This study supports the research findings of Saputro and Siagian (2017) finding that transformational leadership has a positive and significant effect on employee motivation. The findings of this study support and expand transformational leadership theory into the best approach used by leaders to influence subordinates to achieve organizational goals, with ways of acting that apply inspirational motivation, idealism, individual consideration, charisma, and intellectual stimulation to the people they lead in implementing leader's policies, with full awareness of heart to achieve organizational goals as a common goal.

The transformational leadership theory from Burns (1978) conceptually "Transforming Leadership" is a process in which "leaders and followers help one another to advance to a higher level of morality and motivation". Burns established two concepts: "transforming leadership" and "transactional leadership". According to Burns, the transformation approach creates significant changes in the lives of people and organizations. It redesigns perceptions and values, and changes employees' expectations and aspirations. Unlike in a transactional approach, it is not based on the "give and take" relationship, but on the personality, character, and ability of leaders to make changes through examples, articulation of visions that provide encouraging and challenging goals. Changed leaders are idealized in the sense that they are moral examples that must benefit the team, organization and / or community. Burns theorized that transformation and transactional leadership are mutually exclusive styles. Transactional leaders usually do not struggle for cultural change within organizations but work within existing cultures while transformational leaders can try to change organizational culture.

Bass (1985) broadens the work of Burns (1978) by explaining the psychological mechanisms underlying transformation and transactional leadership; Bass also uses the term "transformational" instead of "transforming." Bass added to the initial concept of Burns (1978) to help explain how transformational leadership can be measured, as well as how it impacts on followers' motivation and performance. The extent to which a leader is transformational, is measured first, in terms of its effect on followers. Leaders feel trust, admiration, loyalty and respect for the leader and because the quality of the leader is willing to work harder than originally thought.

\subsubsection{The Effect of Transformational Leadership on Employee Performance}

The effect of transformational leadership on employee performance, as evidenced by statistically empirical data shows positive and significant path coefficients. Positive path coefficient, means that if transformational leadership is better managed, it will improve employee performance. The theoretical implication of this research is that improvement in transformational leadership will result in changes in employee performance, or in other words the 
existence of employee performance depends on transformational leadership which includes idealism, intellectual stimulation, individual consideration, inspirational motivation, and charisma owned by a leader. Employee performance includes quality, quantity, production time, work effectiveness, independence, work commitment can be managed well by a leader in order to achieve organizational goals. (H2 accepted) which states that "Transformational leadership has a positive and significant effect on employee performance". This happens, because transformational leadership prioritizes idealism, intellectual stimulation, individualized consideration, inspirational motivation, to influence employees at work and improve performance for the achievement of organizational goals as shared goals.

The findings of this study support the research findings of Ratnasi (2017); Wardani, (2017); Andinasari et al. (2017); Suyanto et al. (2017); Bawaradi et al. (2017); Saputro and Siagian (2017); Hanantoko and Nugraheni (2017); Haryanto (2017) found transformational leadership to have a positive and significant effect on employee performance. The theoretical implication of this research is that improvement in transformational leadership will result in changes in employee performance, or in other words the existence of employee performance depends on transformational leadership which includes idealism, intellectual stimulation, individual consideration, inspirational motivation, and charisma owned by a leader. Employee performance includes quality, quantity, production time, work effectiveness, independence, work commitment can be managed well by a leader in order to achieve organizational goals. Transformational leadership can improve employee performance through the best approach used by leaders to influence subordinates to achieve organizational goals, by ways of acting that apply inspirational motivation, idealism, individual consideration, charisma, and intellectual stimulation to the people they lead in implementing policies leader policy, with full awareness of the heart to achieve organizational goals as a common goal.

\subsubsection{The Effect of Employee Motivation on Compensation}

The effect of employee motivation on compensation, as evidenced by statistically empirical data shows positive and significant path coefficients. Positive path coefficient, means that if employee motivation is improved, it will increase compensation. The theoretical implication of this study is that improvement in employee motivation will result in changes in compensation which includes salaries, benefits, incentives, services obtained by employees, or in other words the existence of compensation depends on employee motivation which includes extrinsic motivation and intrinsic motivation. Employees who want to get high compensation must also have high motivation to work and contribute to the company's income. Employee motivation compensation must be managed well by management in order to achieve organizational goals. (H3 accepted) which states that "Employee motivation has a positive and significant effect on compensation". This happens, because every employee has motivation in doing work to get compensation from the organization or company.

This research broadens the "Expectancy Theory" formulated by Vroom (1964). Vroom explains valence means value, instrumentality is the belief that if people do one thing, it will lead to another, and hope is the probability that an action or effort will produce an outcome. An outcome expected by employees to get from the company is compensation, someone is innovated to do work because he expects compensation. The theoretical implication of this research is the improvement of employee motivation will result in changes in compensation which includes salaries, benefits, incentives, services obtained by employees, or in other words the existence of compensation depends on employee motivation which includes extrinsic motivation and intrinsic motivation. Employees who want to get high compensation must also have high motivation to work and contribute to the company's income. Employee motivation compensation must be managed well by management in order to achieve organizational goals.

\subsubsection{The Effect of Employee Motivation on Employee Performance}

The effect of employee motivation on employee performance, as evidenced by statistically empirical data shows positive and significant path coefficients. Positive path coefficient, means that if employee motivation is improved, it will increase compensation. The theoretical implication of this study is that improvement in employee motivation will result in changes in compensation which includes salaries, benefits, incentives, services obtained by employees, or in other words the existence of compensation depends on employee motivation which includes extrinsic motivation and intrinsic motivation. Employees who want to get high compensation must also have high motivation to work and contribute to the company's income. Employee motivation compensation must be managed well by management in order to achieve organizational goals. (H4 accepted) which states that "Employee motivation has a positive and significant effect on employee performance." This happens, because every employee has the motivation to do work and improve performance for the achievement of the organization or company.

The findings of this study support the research findings of Ratnasi (2017); Andinasari et al. (2017); Yunus and Suwandi (2017); Hanantoko and Nugraheni (2017); Haryanto (2017) found employee motivation to have a positive and significant effect on employee performance. Sunyoto (2012) states that motivation is important because with motivation it is expected that every employee will work hard and enthusiastically to achieve high performance. Mathis and Jackson (2006) suggested that the factors that influence employee performance are employee motivation, employee ability, support received, the state of work performed and the employee's 
relationship with the organization. Motivation is a driving force that makes someone more eager to work effectively and integrated with the aim of getting satisfaction through high performance achievements.

\subsubsection{The Effect of Compensation on Employee Performance}

The effect of compensation on employee performance, as evidenced by statistically empirical data shows positive and significant path coefficients. Positive path coefficient, means that if compensation rises, it will improve employee performance. The theoretical implication of this empirical is that any increase or improvement in compensation will result in an increase in employee performance. (H5 accepted) which states that "Compensation has a positive and significant effect on employee performance." This happens, because every employee who receives a fair compensation from the company will be more eager to work to show high performance or performance, so that in the next period can received an award from the company.

The findings of this study support the study of Qustolani (2017) finding that compensation has a positive and significant effect on employee performance. Robbins (1993) explains that compensation can play a role in increasing work performance and job satisfaction, if compensation is felt (a) to be appropriate with the ability and productivity of employees; (b) relating to work performance; and (c) adjusting individual needs. In this case the company must pay good attention to the arrangements for giving compensation to employees properly. The employees assess the compensation provided is inadequate, then the performance and job satisfaction of employees will decrease, conversely if the compensation given is high then the employee's performance and job satisfaction will increase.

\subsection{Discussion of Fit Model}

The FIT value indicates the predictive-relevance value of the total variance explained by all variables in the structural model. FIT values range from 0 to 1 . The closer to 1 , the variance of all variables in the model can explain a lot of information by empirical data. The AFIT (adjusted FIT) value is almost the same as the FIT, but it has taken into account the complexity of the model. AFIT can be used to compare existing models. Given the more variables in the model will affect the value of the FIT is getting bigger because of the diversity of data, and the model is more complex so that to adjust to the existing variables can use a corrected FIT (AFIT).

Based on the results of the GSCA analysis, the FIT value of 0.759 implies that the dependent latent variable can be explained by the independent latent variable in the structural model of $75.9 \%$, or in other words the model can explain the empirical phenomenon of $75.9 \%$ with the data in the variables studied, while the remaining 24.1 $\%$ is explained by other variables that have not been included in the research model and error. Given the more variables in the model will affect the value of the FIT is getting bigger because of the diversity of data, and the model is more complex so that to adjust to existing variables can use AFIT (adjusted FIT). AFIT value of 0.756 implies that the dependent latent variable can be explained by the independent latent variable in the model by $75.6 \%$, or the model can explain empirical phenomena by $76.2 \%$, with data in the variables studied, while the remaining $24.4 \%$ is explained by variables not yet included in the research and error model.

Overall the estimated model of this study shows that, first, transformational leadership strongly influences employee motivation (X-> Y1) of $64.8 \%$. This means that transformational leadership is the main determinant of employee motivation. Second, employee motivation affects compensation (Y1-> Y2) amounting to 59.5\%. This means that employee motivation is a determinant of compensation. Third, transformational leadership affects employee performance (X-> Y3) is $49.5 \%$. This means that transformational leadership is a determinant of employee performance. Fourth, compensation affects employee performance (Y1-> Y3) is 24.5\%. Fifth, employee motivation affects employee performance (Y1-> Y3) is $24.2 \%$.

\section{CONCLUSIONS}

Based on the description and discussion of the research findings it is concluded as follows:

The effect of transformational leadership on employee motivation, as evidenced by statistically empirical data shows positive and significant path coefficients. The positive path coefficient means that transformational leadership is better managed and will increase employee motivation. The theoretical implication of this research is the improvement of transformational leadership will result in changes in employee motivation, or in other words the existence of employee motivation depends on transformational leadership. Employee motivation includes extrinsic motivation and intrinsic motivation can be managed well by a leader in order to achieve organizational goals. (H1 accepted) which states that "Transformational leadership has a significant effect on employee motivation". This happens, because transformational leadership prioritizes idealism, intellectual stimulation, individualized consideration, inspirational motivation, to influence employees in order to achieve organizational goals as shared goals.

The influence of transformational leadership on employee performance, as evidenced by statistically empirical data shows positive and significant path coefficients. Positive path coefficient, means that if transformational leadership is better managed, it will improve employee performance. The theoretical implication of this research is that improvement in transformational leadership will result in changes in employee performance, 
or in other words the existence of employee performance depends on transformational leadership which includes idealism, intellectual stimulation, individual consideration, inspirational motivation, and charisma owned by a leader. Employee performance includes quality, quantity, production time, work effectiveness, independence, work commitment can be managed well by a leader in order to achieve organizational goals. (H2 accepted) which states that "Transformational leadership has a positive and significant effect on employee performance". This happens, because transformational leadership prioritizes idealism, intellectual stimulation, individualized consideration, inspirational motivation, to influence employees at work and improve performance for the achievement of organizational goals as shared goals.

The effect of employee motivation on compensation, as evidenced by statistically empirical data shows positive and significant path coefficients. Positive path coefficient, means that if employee motivation is improved, it will increase compensation. The theoretical implication of this study is that improvement in employee motivation will result in changes in compensation which includes salaries, benefits, incentives, services obtained by employees, or in other words the existence of compensation depends on employee motivation which includes extrinsic motivation and intrinsic motivation. Employees who want to get high compensation must also have high motivation to work and contribute to the company's income. Employee motivation compensation must be managed well by management in order to achieve organizational goals. (H3 accepted) which states that "Employee motivation has a positive and significant effect on compensation". This happens, because every employee has motivation in doing work to get compensation from the organization or company.

The effect of employee motivation on employee performance, as evidenced by statistically empirical data shows positive and significant path coefficients. Positive path coefficient, means that if employee motivation is improved, it will increase compensation. The theoretical implication of this study is that improvement in employee motivation will result in changes in compensation which includes salaries, benefits, incentives, services obtained by employees, or in other words the existence of compensation depends on employee motivation which includes extrinsic motivation and intrinsic motivation. Employees who want to get high compensation must also have high motivation to work and contribute to the company's income. Employee motivation compensation must be managed well by management in order to achieve organizational goals. (H4 accepted) which states that "Employee motivation has a positive and significant effect on employee performance." This happens, because every employee has the motivation to do work and improve performance for the achievement of the organization or company.

The effect of compensation on employee performance, as evidenced by statistically empirical data shows positive and significant path coefficients. Positive path coefficient, means that if compensation rises, it will improve employee performance. The theoretical implication of this empirical is that any increase or improvement in compensation will result in an increase in employee performance. (H5 accepted) which states that "Compensation has a positive and significant effect on employee performance." This happens, because every employee who receives a fair compensation from the company will be more eager to work to show high performance or performance, so that in the next period can received an award from the company. Robbins (1993) explains that compensation can play a role in increasing work performance and job satisfaction, if compensation is felt (a) to be appropriate with the ability and productivity of employees; (b) relating to work performance; and (c) adjusting individual needs. In this case the company must pay good attention to the arrangements for giving compensation to employees properly. The employees assess the compensation provided is inadequate, then the performance and job satisfaction of employees will decrease, conversely if the compensation given is high then the employee's performance and job satisfaction will increase.

\section{Recommendations}

\subsection{Recommendations for Advanced Research}

Based on the discussion of the findings and limitations of this study that have been described in the previous section, it is recommended for future research as follows: Future research can add other variables that have not been included in this research model, to obtain a more comprehensive research model. For example, government policy variables, and corporate governance variables.

\subsection{Recommendations for Companies}

Contribution of this research to companies or organizations, especially the Kupang District Drinking Water Company, the results of this study are expected to provide useful input in decision making or policy in the field of personnel to consider transformational leadership, employee motivation, compensation and employee performance in ensuring the survival of the organization or companies and workers. Practically for companies and governments it is suggested as follows:

1) Apply transformational leadership as the best approach used by leaders to influence subordinates by applying inspirational motivation, idealism, individual consideration, charisma, and intellectual stimulation to the people they lead in implementing policies with mindful hearts to achieve organizational goals as a common goal .

2) Generating employee motivation, both intrinsic and extrinsic motivation. Employee motivation in doing work 
will be very decisive to get involved really working. Employee motivation will determine whether employees really develop competencies, knowledge, and skills at work. Employee motivation will determine to truly commit to the organization or company and work wholeheartedly for the progress of the organization. Employee motivation determines the level of employee performance in achieving organizational goals as shared goals.

3) Provide reasonable compensation to employees, and encourage employees to improve superior performance in achieving organizational goals as a common goal.

\subsection{Recommendations for the Government}

The contribution of this study recommends the government as a regulator in the development and utilization of human resources. The contribution of this study recommends the government as a regulator in the development and utilization of human resources, and organizational structuring. The results of this study provide useful information input in making decisions or policies in the field of personnel to consider transformational leadership, motivation and expectations of employees, compensation and employee performance to ensure the survival of the organization or company and workers. The Ministry of Manpower is expected to increase knowledge in terms of selecting and making labor regulation decisions in Indonesia that is effective and efficient, and benefits all parties, because labor is a strategic resource that has the highest benefit in competitive advantage.

\section{Reference}

Andinasari., Sujanto, Bedjo and Mukhtar, Mukhneri.(2017). The Effect Transformational Leadership, Personality and Job Performance Administration Employees. International Journal of Human Capital Management (IJHM).

Armstrong, M. (2009). A Handbook of Personnel Management Practices, London: Kogan Page Limited.

Bass, B.M. (1985). Leadership and Performance beyond expectations. New York: Free Press.

Bass, B.M., Avolio, B.J., Jung, D.I., and Berson Y. (2003). Predicting Unit Performance by Assessing Transformational and Transactional Leadership. Journal of Applied Psychology, Vol.88.

Bawaradi, Meike., Tewal, B. dan Raintung, Michael Ch. (2017). Effect of Transactional Leadership and Organizational Culture on Employee Performance at PT. Mando FIF Group. Journal EMBA Vol. No. 2.

Burns, J.M. (1978). Leadership, N.Y, Harper and Row

Crewell, J. W. (2009). Research Design: Qualitative, Quantitative, and Mixed Method Approaches. 3th Edition. SAGE Publication, Inc. California.

Dessler, G. (2015). Human Resource Management. 4th edition. Jakarta. Salemba Empat.

Gibson, Ivancevich, Dennelly, and Konopaske. (2006). Organizational Behavior - Structure - Process. Subtitles by Nunuk Adiarni and Lyndon Saputra. Bina Putra. Jakarta.

Hanantoko, Destu Haji dan Nugraheni, Rini. (2017). The Effect of Work Motivation on Leadership and Organizational Culture on Performance (Study of Sales Employees at PT. Industrian Mr Djenggot Bengas), Semarang. Diponegoro Journal of Management, Vol. VI (4).

Haryanto, Puji. (2017). The Effect of Leadership Style, Motivation and Work Experience on Employee Performance (Employee Study at PT. TOP Apparel in Wonogiri). Diponegoro Journal of Accounting. Vol. VI No. 4.

Herzberg, F., W, Mausner, B and Snyderman, B. (1957). The Motivation to Work, Wiley, New York.

Locander, W.B., F. Hamilton, D. Ladik and J. Stuart. (2002). developing a leadership-rich culture: The missing link to creating a market-focused organization, Journal of Market-Focused Management, Vol. 5, pp. 149163.

Mathis, Robert L and Jackson John H. (2002). Human Resource Management (Translation) Book 2. Ninth Edition. Jakarta: Salemba Empat Publisher.

Moorhead dan Griffin. 2013. Organizational Behavior. Jakarta: Salemba Empat.

Qustolani, H. Asep. (2017). Effect of Job Satisfaction, Procedural Justice and Compensation on Employee Performance (Case Study in the Rattan Industry in Leuwimunding Majalengka District). Scientific Journal of Management and Accounting (Maksi, Vol 3 (1).

Ratnasi, Cicih.(2017). The Effect of Leadership Style, Discipline, Motivation and Performance Ether Partially or Simultan Neously in east Jakarta Area. International Journal of Human Capital Management (IJHM)

Robbins, S. P. (1993). Organizational Behavior. Gramedia.

Robbins, S. P. (2007). Organizational Behavior. B. Molan, ed., New Jersey Prentice Hall.

Robbins, S dan Coulter, M. (2007). Management. Eighth edition, PT. Indeks. Jakarta.

Robbins, S. P. (2015). Organizational Behavior. Second Edition. Jakarta: PT. Prehallindo.

Saputro, Guntur Bayu and Siagian, Hotlan. (2017). The Effect of Leadership Style on Employee Performance Through Intervening Variables in Work Motivation Head Office PT. Marifood. AGORA, Vol. 5 (3).

Sekaran, U. (2003). Research Method For Business, A Skill Building Approach. John Wiley and Sons, Inc. New 
York.

Sharma, S. (1996). Applied Multivariate Techniques. John Wiley and Sons, Inc.

Siagian, Sondang P. (2013). Human Resource Management. PT. Bumi Aksara. Jakarta.

Simamora, B. (2004). Marketing Research: Philosophy, Theory, and Application. PT. Gramideia Pustaka Utama. Jakarta.

Sugiyono, (2012). Statistics for Research. Bandung: CV. Alfabeta.

Sunyoto, Danang. (2012). Questionnaire Theory and Analysis of Human Resource Data (Research Practices). Jogyakarta.

Suyanto, Bedjo., Akbar, Ma'ruf and Apriyadi, Darmawan.(2017). The Effect of Competence, Leadership, and Management Innovation Over the Performance of Structural Official of Echelon IV B. International Journal of Human Capital Management (IJHM).

Taylor, F W. (1911).Principles of Scientific Management. Harper, New York.

Vroom, V. (1964). Work and Motivation. Wiley, New York.

Wardani, Kusuma Nia (2017). Influence of Competence, Transformational Leadership, Sosial Capital and Performance on Employee Careers. International Journal of Human Capital Management, Vol 1 (2).

Wood, A. M., Joseph, S., and Maltby, J. (2008). Gratitude uniquely predicts satisfaction with life: Incremental validity above the domains and facets of the five factor model. Personality and Individual Differences, 45, 49-54.

Yunus, Sri Rukmiati dan Suwandi. (2017). The Effect of Work Motivation and Discipline on the Performance of City Tegal Police Members. Journal Multiplier, Vol. 1 (2). 


\section{Appendix: Research Questionnaire PERCEPTION OF RESPONDENTS \\ Instructions}

Choose one of the alternative answers that you think is best suited to the conditions. Selection is done by giving a check mark $(\sqrt{ })$ to the available answer choices. Information:

$1=$ Strongly Disagree $(\mathrm{SD})$

$2=$ Disagree (DIS)

$3=$ Doubtful (DB)

$4=$ Agree $(\mathrm{A})$

$5=$ Strongly agree $(\mathrm{SA})$

\begin{tabular}{|c|c|c|c|c|c|c|}
\hline \multirow{3}{*}{ No } & \multirow{3}{*}{ STATEMENT } & \multicolumn{5}{|c|}{ ANSWER } \\
\hline & & SD & DIS & DB & A & SA \\
\hline & & 1 & 2 & 3 & 4 & 5 \\
\hline $\mathbf{I}$ & TRANSFORMATIONAL LEADERSHIP & & & & & \\
\hline 1 & Leaders always create new ideas for employees (staff) & & & & & \\
\hline 2 & $\begin{array}{l}\text { Leaders always provide an intellectual stimulus for employees (staff) to } \\
\text { continue learning. }\end{array}$ & & & & & \\
\hline 3 & Leaders always provide motivation and inspiration for employees (staff). & & & & & \\
\hline 4 & $\begin{array}{l}\text { Leaders always give priority to an individual approach to each employee } \\
\text { (staff). }\end{array}$ & & & & & \\
\hline 5 & Leaders have an attraction that influences employees (staff) at work. & & & & & \\
\hline II & EMPLOYEE MOTIVATION & & & & & \\
\hline 1 & The company provides a fair salary and salary increase. & & & & & \\
\hline 2 & $\begin{array}{l}\text { The company provides fair promotion opportunities based on performance } \\
\text { or achievement. }\end{array}$ & & & & & \\
\hline 3 & I was given the opportunity to develop knowledge and skills. & & & & & \\
\hline 4 & The company guarantees safety at work. & & & & & \\
\hline 5 & I got compliments from superiors. & & & & & \\
\hline 6 & I get praise and respect from coworkers & & & & & \\
\hline 7 & I am happy and try to achieve more. & & & & & \\
\hline 8 & I have freedom at work. & & & & & \\
\hline III & COMPENSATION & & & & & \\
\hline 1 & The company gives me a fair salary for me & & & & & \\
\hline 2 & $\begin{array}{l}\text { The company provides compensation in the form of benefits other than } \\
\text { salaries. }\end{array}$ & & & & & \\
\hline 3 & The company provides intensive out of salary based on merit. & & & & & \\
\hline 4 & The company gave me an award. & & & & & \\
\hline IV & EMPLOYEE PERFORMANCE & & & & & \\
\hline 1 & I work according to the quality standards of the targeted work. & & & & & \\
\hline 2 & I completed a number of jobs that exceeded the target. & & & & & \\
\hline 3 & I finish work on time. & & & & & \\
\hline 4 & I work more effectively according to the time and cost. & & & & & \\
\hline 5 & I work independently without being watched by others & & & & & \\
\hline 6 & I work earnestly with determination. & & & & & \\
\hline
\end{tabular}

*** Thank you for your participation *** 